\title{
Clustering of physical inactivity and low fruit and vegetables intake and associated factors in young adults
}

\author{
Agregamento entre a inatividade física e consumo \\ de frutas, legumes e verduras e fatores \\ associados em adultos jovens
}

Rafael Miranda TASSITANO'

Maria Cecília Marinho TENÓRIO'

Poliana Coelho CABRAL²

Giselia Alves Pontes da SILVA ${ }^{3}$

A B S T R A C T

\section{Objective}

To investigate the cluster of physical inactivity and low fruit and vegetable intake and the associated factors in university students.

\section{Methods}

This cross-sectional study included a representative sample $(n=717)$ of Universidade Federal Rural de Pernambuco students. Low fruit and vegetable intake was defined as an intake of less than five servings a day and physical inactivity was defined as exercising less than 150 minutes a week. The independent variables were gender, age, socioeconomic status, school year, shift, and study time. Clustering was determined by comparing the observed prevalence with the expected prevalence for all possible risk-factor combinations. Logistic regression analysis, performed by the software Statistical Package for the Social Sciences 17.0 with a significance level of 5\% $(p<0.05)$, considered the presence of both risk behaviors adjusted to the independent variables.

\section{Results}

The prevalence of low fruit and vegetable intake was $81.7 \%(\mathrm{Cl} 95 \%=78.1-84.3)$ and of physical inactivity was $65.8 \%(C 195 \%=62.2-69.4)$. Most students (58.6\%, C195\%=55.3-62.2) were exposed to both risk factors simultaneously, while $11.0 \%(\mathrm{Cl} 95 \%=8.9-13.5)$ were exposed to neither. Full-time students have a risk 1.45

1 Universidade Federal Rural de Pernambuco, Departamento de Educação Física. R. Dom Manoel de Medeiros, s/n., Dois Irmãos, 52171-900, Recife, PE, Brasil. Correspondência para/Correspondence to: RM TASSITANO. E-mail: <rafael.tassitano@gmail.com>.

2 Universidade Federal de Pernambuco, Centro de Ciências da Saúde, Departamento de Nutrição. Recife, PE, Brasil.

3 Universidade Federal de Pernambuco, Centro de Ciências da Saúde, Departamento de Saúde Materno Infantil. Recife, PE, Brasil. 
times greater of simultaneous exposure. Juniors and seniors are, respectively, 1.88 and 2.80 times more likely to present both risk behaviors.

\section{Conclusion}

Although complex, the behaviors are modifiable, and both the healthy and the unhealthy behaviors tend to cluster. The implementation of an intervention that targets both risk behaviors is needed. Different strategies can be used, such as providing areas for physical activity and for learning about healthy and risk behaviors.

Indexing terms: Healthy behaviors. Lifestyle. Risk factors.

\section{RE S U M O}

\section{Objetivo}

Investigar o cluster da inatividade física e o baixo consumo de frutas, legumes e verduras e os fatores associados ao contexto universitário.

\section{Métodos}

Estudo transversal com uma amostra representativa $(n=717)$ de estudantes universitários da Universidade Federal Rural de Pernambuco. Considerou-se baixo consumo de frutas, legumes e verduras a frequência de consumo menor que 5 porções/dia, e inatividade física a prática inferior a 150 minutos/semana. As variáveis independentes foram: sexo, idade, nível socioeconômico, turno, tempo de permanência na instituição e período do curso. 0 cluster foi calculado comparando-se a prevalência observada e a esperada em todas as possibilidades de agrupamento. Para a análise de regressão logística, considerou-se a presença dos dois comportamentos simultaneamente ajustada às variáveis independentes, sendo as análises realizadas no Statistical Package for the Social Sciences $17.0(p<0,05)$.

\section{Resultados}

A prevalência de baixo consumo de frutas, legumes e verduras foi de 81,7\% (IC95\%=78, 1-84,3), e da inatividade física foi de 65,8\% (IC95\%=62,2-69,4). Verificou-se que 58,6\% (IC95\%=55,3-62,2) apresentaram exposição aos dois comportamentos simultaneamente, enquanto $11,0 \%$ (IC95\%=8,9-13,5) não apresentaram nenhuma exposição. Permanecer dois turnos na universidade aumenta 1,45 vez a chance de exposição simultânea. 0 fato de estar nos dois últimos anos do curso aumenta 1,88 vez a chance de baixo consumo de frutas, legumes e verduras, e 2,80 vezes a chance de inatividade física.

\section{Conclusão}

Os comportamentos são modificáveis, apesar de complexos, e a presença ou ausência de um tende a influenciar o outro; sendo assim, sugere-se uma intervenção integrada que focalize ambos. Diferentes estratégias, como oferta de espaços para a prática de atividade física e de ações em educação e saúde para ambos os comportamentos podem ser utilizadas.

Termos de indexação: Comportamentos saudáveis. Estilo de vida. Fatores de risco.

\section{NTROD UCTION}

According to the World Health Organization (WHO), more than one-third of the global deaths may be attributed to a small number of factors, and the main ones are high blood pressure (responsible for $13 \%$ of the deaths), smoking (9\%), physical inactivity (6\%), and excess weight $(5 \%)^{1}$. Except for smoking, all other causes are related to physical inactivity and/or low fruit and vegetable intake ${ }^{1,2}$.
Despite the actions proposed in the last decades, physical activity and fruit and vegetable intake have not increased significantly in most countries $^{1,2}$. Health-risk behaviors tend to cluster, that is, there is a causal network between exposure to one behavior and the presence of another ${ }^{3-14}$. Moreover, evidence shows that the strategies that focus on actions involving multiple behaviors have a greater impact than interventions on isolated behaviors ${ }^{11,15-18}$. 
Nevertheless, few studies have investigated the clustering of behaviors and associated factors, especially in the youth ${ }^{5-10,12,13}$. Most studies involved adults and elderly from high-income countries ${ }^{5-10,12,13}$. The transition period between adolescence and adulthood is characterized by significant social relationship and environmental changes that may negatively impact health actions, attitudes, and behaviors, especially in the young who enter university ${ }^{14,19-22}$. Although university is admittedly an educational environment, the prevalence of physical inactivity and low fruit and vegetable intake is high ${ }^{19}$. Information about these isolated behaviors is already available in Brazil, but few studies have looked at clustering ${ }^{23-26}$, and none regarded the university context.

Colares et al.27, for example, studied the health behaviors of students from public highereducation institutions of Recife, but they did not investigate whether these behaviors were clustered or whether they were associated with attending university. Given the above information, the present study aims to investigate clustering between physical inactivity and low fruit and vegetable intake, and whether this possible clustering is associated with university-related variables.

\section{METHODS}

This cross-sectional study was developed at the Universidade Federal Rural de Pernambuco (UFRPE). Male and female UFRPE students aged 18 to 24 years were eligible. The exclusion criteria were: (a) intellectual disability; (b) students in student exchange programs (Brazilian or otherwise), and (c) distance learning students and from campuses other than the main campus. The sample size was calculated based on a population size of 7,287 students, a prevalence of $50 \%$ for multiple outcomes, an error of $5 \%$, and a sampling design effect of two. The estimated sample size was 695 students, but since the proportion of students aged more than 24 years was unknown and to compensate for eventual sample losses and participation refusals, the sample size was multiplied by 1.2 , totaling 834 students.

Cluster sampling was done in two stages. The first stage included students from all academic majors, each academic major being a cluster. The academic majors were then selected randomly considering the following stratification criteria: (a) year density per academic major, (b) number of students per academic major. The second stage considered the proportion of males and females per year and academic major. The software Research Randomizer performed the random samplings.

Two questionnaires were used for collecting data, one to measure fruit and vegetable intake frequency ${ }^{28}$ and the other to determine the level of physical activity ${ }^{29}$. Sociodemographic, socioeconomic, and education institution data were also collected. Fruit and vegetable intake data were collected by a semiquantitative food frequency questionnaire with 94 items (10 fruits and 11 vegetables) developed and validated by Slater et al. ${ }^{28}$. This instrument includes the serving size of each food item $^{28}$. The available intake frequencies were monthly, weekly, and daily. The reference period was the six months that preceded the interview. Thus, the number of fruit and vegetable servings per day was given by adding the number of servings of all the fruit and vegetable items consumed daily. Those who reported a fruit and vegetable intake below five servings per day were considered at risk. A pilot study found that the intake frequency presented good reproducibility $(r=0.56-0.83)$. The interviews were in person, which allowed the participants to clarify the amounts consumed.

The International Physical Activity Questionnaire (IPAQ) measured the level of physical activity ${ }^{29}$. The instrument measured the time in minutes spent during a regular week doing moderate and vigorous physical activity at leisure, work, and home, and while commuting. Students 
who exercised less than 150 minutes a week were considered physically inactive. A pilot study found that the level of physical activity presented good reproducibility ( $r=0.67-0.91)$.

The independent variables were age, gender (male/female), socioeconomic status ( $A$, $B, C, D$, and $E)^{30}$, shift (morning, morning and afternoon, and evening), academic major duration, and number of shifts [part-time (1) and full-time (2)]. Socioeconomic status was determined by the instrument Critério de Classificação Econômica Brasil (CCEB, Socioeconomic Classification Criterion Brazil) created by the Associação Brasileira das Empresas de Pesquisa (Abep, Brazilian Association of Research Companies) ${ }^{30}$.

Data were collected as follows: (a) academic major coordinators were contacted to schedule a visit; (b) interviewers were trained for measuring physical activity and food intake, and for administering, filling out, and coding the questionnaire. Data were collected from October to November 2010 by eight interviewers, undergraduate physical education (UFRPE) and nutrition Universidade Federal de Pernambuco (UFPE) students attending the 'Introduction to Research' course. The interviews were conducted in private and lasted 25 to 35 minutes. The students were informed that the information was classified, would not affect their grades, and would only be used in research.

The software Epi Data version 3.1 tabulated the data. The data were entered in two different computers and the files were compared and the mistakes corrected. The data were then exported to the statistical software Statistical Package for the Social Sciences (SPSS) version 17.0. The software Epi Info version 6.04d calculated the confidence intervals.

Data analysis grouped some variables and created others. Age was transformed into two categories, namely 18-21 and 22-24. Students from the socioeconomic classes C, D, and E were grouped. The students were grouped by school year, not semester. Regarding academic majors that lasted more than eight semesters, students of the last years were grouped.

Risk behaviors were binary coded as either 0 (absent) or 1 (present). A variable was then created adding the codes: $0=$ no risk behavior; $1=$ one risk behavior; and 2 =two risk behaviors.

The prevalences of the individual risk behaviors and of all possible combinations stratified by gender were calculated. Clustering occurs when the Observed combination exceeds the Expected prevalence of the combination 5,8,10,12. The expected prevalence of each combination is given by multiplying the individual probability of occurrence of each behavior by its occurrence. When the result observed-to-expected exceeds one, the behaviors are clustered ${ }^{5,8,10,12}$.

Multivariate analysis consisted of binary logistic regression with the reference category being the presence of risk behaviors. The data were analyzed before and after adjustment for the independent variables. The significance level was set at $5 \%(p<0.05)$.

The study was approved by the Human Research Ethics Committee of the UFPE Center for Health Sciences under Protocol number 313/ 2010 and followed the Guidelines and Norms for Human Research.

\section{RE S U L T S}

On data collection day, 748 students were present, two $(0.2 \%)$ of which were exchange students and so excluded, and 29 (4.0\%) refused to participate. Therefore, 717 students joined the study. Table 1 shows the sample's university and health behavior characteristics stratified by gender. Only $18.3 \%$ (Confiance Interval of 95\% - 95\% $\mathrm{Cl}=15.6-21.2)$ of the students consumed enough fruits and vegetables, and $34.2 \%$ were physically active $(95 \% \mathrm{Cl}=30.7-37.7)$.

The general prevalences of risk behaviors were $81.7 \%(95 \% \mathrm{Cl}=78.1-84.3)$ for inadequate fruit and vegetable intake and $65.8 \%$ $(95 \% \mathrm{Cl}=62.2-69.4)$ for physical inactivity, and 
the differences between genders were significant. More females studied during the day than males $(p<0.05)$ (Table 1).

More than half $(58.6 \%, 95 \% \mathrm{Cl}=55.3-$ 62.2) the sample presented both risk behaviors, while $30.4 \%(95 \% \mathrm{Cl}=27.1-33.8)$ presented only one, and $11.0 \%(95 \% \mathrm{Cl}=8.9-13.5)$ presented none. The prevalences of the presence and absence of both risk behaviors differed significantly between genders, with the former being more prevalent in women.

Table 2 shows the Observed and Expected results of all possible combinations of the two behaviors stratified by gender. The behaviors clustered in males and females with an Observedto-Expected ratio of 1:1 for both genders. The clustering of healthy behaviors (adequate fruit and vegetable intake and level of physical activity) also

Table 1. Sociodemographic, socioeconomic, academic major, and risk behavior characteristics of university students $(n=717)$, from Recife (PE), Brazil, 2010.

\begin{tabular}{|c|c|c|c|}
\hline Variables & Men $(n=316) \%$ & Women $(n=401) \%$ & $p$ value $^{*}$ \\
\hline Low fruit and vegetable intake* & 78.5 & 84.3 & 0.05 \\
\hline Physical inactivity** & 57.6 & 72.3 & 0.00 \\
\hline \multicolumn{4}{|l|}{ Number of risk factors } \\
\hline 2 & 51.3 & 64.3 & \multirow[t]{4}{*}{0.00} \\
\hline 1 & 33.5 & 27.9 & \\
\hline 0 & 15.2 & 7.7 & \\
\hline \multicolumn{3}{|c|}{ Sociodemographic factors } & \\
\hline \multicolumn{4}{|l|}{ Age (years) } \\
\hline 18 & 19.9 & 15.2 & \multirow[t]{7}{*}{0.08} \\
\hline 19 & 19.6 & 18.0 & \\
\hline 20 & 17.7 & 12.7 & \\
\hline 21 & 11.7 & 16.0 & \\
\hline 22 & 12.0 & 13.5 & \\
\hline 23 & 9.5 & 14.0 & \\
\hline 24 & 9.5 & 10.7 & \\
\hline \multicolumn{4}{|l|}{ Socioeconomic status ${ }^{* \star *}$} \\
\hline A & 14.8 & 16.1 & \\
\hline B & 37.3 & 41.3 & \\
\hline C & 47.6 & 42.3 & 0.72 \\
\hline D & 0.3 & 0.3 & \\
\hline E & 0.0 & 0.0 & \\
\hline \multicolumn{4}{|c|}{ Academic major features } \\
\hline \multicolumn{4}{|l|}{ Year } \\
\hline First (freshman) & 44.9 & 41.9 & 0.87 \\
\hline Second (sophomore) & 32.3 & 34.4 & \\
\hline Third (junior) & 11.1 & 11.7 & \\
\hline Fourth (senior) & 11.7 & 12.0 & \\
\hline \multicolumn{4}{|l|}{ Study time } \\
\hline Part-time & 42.7 & 36.2 & 0.07 \\
\hline Full-time & 57.3 & 63.8 & \\
\hline \multicolumn{4}{|l|}{ Shift } \\
\hline Day & 63.3 & 70.6 & 0.05 \\
\hline Evening & 36.7 & 29.4 & \\
\hline
\end{tabular}

Note: ${ }^{*}<5$ servings/day; Chi-square test for heterogeneity; ${ }^{* *}<150$ minutes/week;Chi-square test for trend; ${ }^{* * *}$ Economic Classification Criterion of Brazil by Associação Brasileira das Empresas de Pesquisa (Brazilian Association of Research Companies). 
occurred, with an observed-to-expected ratio of 1.67 for males and 1.80 for females. Adequate fruit and vegetable intake and physical inactivity was observed only in women, with an Observedto-Expected ratio of 1.07, while inadequate fruit and vegetable intake and physical activity was found in men and women (Table 2).

Physical inactivity presented a near-linear association with school year in men and women.
Physical inactivity increases with school year. Figure 1 shows a near-linear association between school year and exposure to risk behaviors, and Figure 2 shows the same near-linear association for women only.

In unadjusted logistic regression, three independent variables were significantly associated with the presence of two risk behaviors: gender, socioeconomic status, and

Table 2. Prevalence of the clustering of four health-related behaviors presented by university students from Recife (PE), Brazil, stratified by gender ( $n=717), 2010$.

\begin{tabular}{|c|c|c|c|c|c|c|c|c|}
\hline \multirow{2}{*}{ Behaviors } & \multirow{2}{*}{ Low fruit and vegetable intake } & \multirow{2}{*}{ Physical inactivity } & \multicolumn{3}{|c|}{ Men $(n=226)$} & \multicolumn{3}{|c|}{ Women $(n=374)$} \\
\hline & & & $\mathrm{O}(\%)$ & $E(\%)$ & O/E & $\mathrm{O}(\%)$ & $E(\%)$ & O/E \\
\hline 2 & + & + & 51.3 & 45.2 & 1.13 & 64.3 & 60.9 & 1.10 \\
\hline \multirow{2}{*}{1} & - & + & 11.0 & 11.9 & 0.92 & 11.0 & 10.8 & 1.07 \\
\hline & + & - & 33.7 & 32.7 & 1.03 & 23.7 & 22.6 & 1.04 \\
\hline 0 & - & - & 15.2 & 9.1 & 1.67 & 7.7 & 4.3 & 1.80 \\
\hline
\end{tabular}

Note: +: Factor present; -: Factor absent. *Observed value: 0.

O: Observed; E: Expected.

Table 3. Unadjusted and adjusted analyses of the association between sociodemographic, socioeconomic, and academic major variables and the presence of two health-risk factors in university students $(n=717)$, of Recife (PE), Brazil, 2010.

\begin{tabular}{|c|c|c|c|}
\hline Variables & $\%$ & Unadjusted PR (95\%CI) & Adjusted $^{*}$ PR $(95 \% \mathrm{Cl})$ \\
\hline Gender & & 0.00 & 0.00 \\
\hline Male & 51.3 & 1.00 & 1.00 \\
\hline Female & 64.3 & $1.72(1.27-2.31)$ & $1.87(1.41-2.54)$ \\
\hline Age (years) & & $p=0.67$ & $p=0.20$ \\
\hline $18-21$ & 57.8 & 1.00 & 1.00 \\
\hline $22-24$ & 59.4 & $1.06(0.80-1.43)$ & $1.29(0.90-1.77)$ \\
\hline Socioeconomic status & & $p=0.005$ & $p=0.007$ \\
\hline A & 53.5 & 1.00 & 1.00 \\
\hline B & 55.6 & $1.12(0.82-1.66)$ & $1.19(0.88-1.87)$ \\
\hline$C, D$, and $E$ & 65.5 & $1.22(1.10-1.76)$ & $1.33(1.18-1.91)$ \\
\hline Shift & & $p=0.22$ & $p=0.51$ \\
\hline Day & 60.1 & 1.00 & 1.00 \\
\hline Evening & 55.4 & $0.82(0.60-1.12)$ & $0.88(0.71-1.21)$ \\
\hline Study time & & 0.27 & 0.04 \\
\hline Part-time & 56.1 & 1.00 & 1.00 \\
\hline Full-time & 60.2 & $1.18(0.87-1.60)$ & $1.45(1.12-2.09)$ \\
\hline School year & & $p=0.004$ & $p=0.03$ \\
\hline First (freshman) & 53.5 & 1.00 & 1.00 \\
\hline Second (sophomore) & 59.6 & $1.30(0.69-2.50)$ & $1.51(0.88-2.74)$ \\
\hline Third (junior) & 63.4 & $1.54(0.90-2.61)$ & $1.88(1.12-3.15)$ \\
\hline Fourth (senior) & 69.4 & $1.97(1.17-3.28)$ & $2.80(1.40-4.18)$ \\
\hline
\end{tabular}

Note: *Adjusted for all variables.

PR: Prevalence Ratio; C195\%: Confidence Interval of $95 \%$. 
school year (Tabela 3). Women presented a Prevalence Ratio (PR) of $1.72(95 \% \mathrm{Cl}=1.27-2.31)$ in relation to men, and the students in classes $C, D$, and E presented a PR of $1.22(95 \% C l=1.10$ 1.76) in relation to students in classes $A$ and $B$. $A$ significant linear trend was also observed between school year and the clustering of both study behaviors. In other words, as graduation approaches, the risk of being exposed to both risk behavior increases $(p<0.05)$.

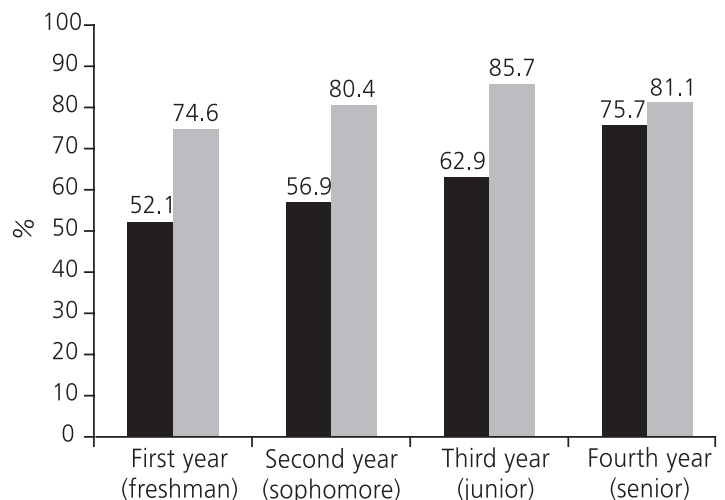

- Physical Inactivity ( $p=0.01)$

Low fruit and vegetable intake $(p=0.18)$

Figure 1. School year presenting a near-linear association with physical inactivity and low fruit and vegetable intake in university students ( $n=717)$, from Recife (PE), Brazil, 2010.

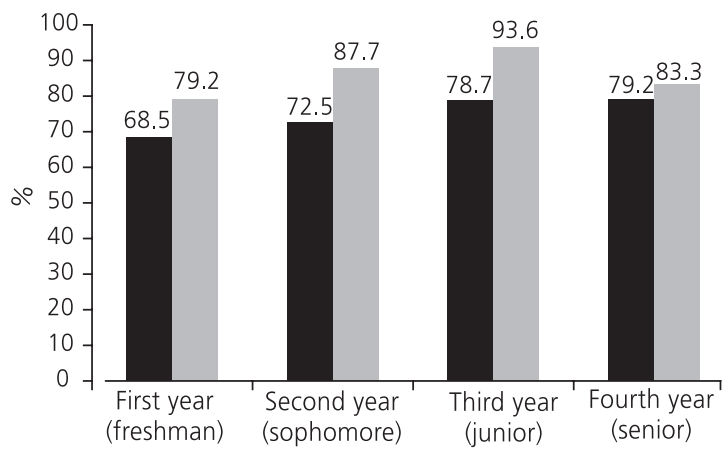

Physical Inactivity $(p=0.05)$

Low fruit and vegetable intake $(p=0.10)$

Figure 2. School year presenting a near-linear association with physical inactivity and low fruit and vegetable intake in female university students $(n=717)$, from Recife $(P E)$, Brazil, 2010.
In adjusted logistic regression, all variables that discriminate outcome remained significant. Additionally, the amount of time students spent at the institution daily also had a significant impact, with full-time presence being a risk factor $(P R=1.35 ; 95 \% C l=1.01-2.04)$ in relation to parttime (Tabela 3).

\section{DISCUSSION}

The objective of the study was to investigate the existence of clustering between physical inactivity and low fruit and vegetable intake, and to verify whether this possible clustering was associated university-related variables. Eight of every ten students do not consume enough fruit and vegetable, and four of every ten are physically inactive. Considering the population of university students, these results corroborate those of Marcondelli et al. ${ }^{31}$, and exceed those of Colares et al. ${ }^{27}$. However, the measurements used by the latter authors did not consider number of servings, and those same authors did not investigate physical activity frequency and intensity.

In the present study, the clustering of low fruit and vegetable intake and physical inactivity has also been found for the general Brazilian population, regardless of cutoff points and

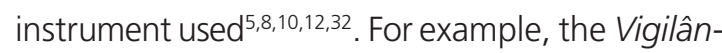
cia de Fatores de Risco e Proteção para Doenças Crônicas por Inquérito Telefônico (Vigitel, Surveillance of Risk and Protective Factors for Chronic Diseases by Telephone Survey) study conducted in 2009 in Brazilian state capitals and Federal District found prevalences of $18.9 \%$ for adequate fruit and vegetable intake and 34.0\% for physical activity ${ }^{33}$. We expected the study participants to adhere more to healthy behaviors because they are young university students with a family income in excess of the national mean. On the other hand, university-related determinants and university infrastructure hinder healthy practices. 
Full-time students were 1.45 times more likely to present clustering of the study risk behaviors than part-time students. Furthermore, as graduation approached, students spent more time in university-related activities, such as tutoring other students, participating in research groups, and attending introduction to science, training, and extension courses, so again hindering healthy practices.

This trend is clearer for physical activity regardless of gender, but is stronger in men: in the first year, the prevalence of physical inactivity was $52.1 \%$, increasing to $75.7 \%$ in the last year. For women, the prevalence was $68.5 \%$ in the first year and $79.5 \%$ in the last. This trend was also observed in fruit and vegetable intake, but it was not significant. The study finding may be explained by the fact that physical activity requires time and greater physical exertion, while dietary patterns are affected less. This trend was also confirmed by adjusted logistic regression: junior and senior students were two to three times more likely to be exposed to both risk behaviors.

The clustering of both risk behaviors was found in $51.3 \%$ of the men and $64.3 \%$ of the women $(p<0.05)$. On the other hand, the clustering of both healthy behaviors was found in $15.2 \%$ of the men and $7.7 \%$ of the women. Physical activity seems to account for the gender difference since approximately $50.0 \%$ of the men are active, against $25.0 \%$ of the women.

In general, healthy and unhealthy behaviors tend to cluster, but the O/E ratio of both risk behaviors was higher than that of both healthy behaviors in both genders. This shows that there is a stronger clustering between healthy behaviors than between risk behaviors. Other studies have also found this same relationship $5,8,10,12$, which suggests that these behaviors have a similar degree of complexity.

The study sampling procedure, which took into account the proportion of students enrolled in each academic major and shift, and the proportion of males and females, allows extrapolating the results to all UFRPE students.
The present study investigated the clustering of risk behaviors strongly associated with chronic Non-Communicable Diseases (NCD) in an important environment. In addition, this appears to be the first Brazilian study to perform this type of analysis in university students.

The present study has some limitations. Extrapolation of the results to the general youth population requires caution, especially to students attending private institutions and those from other Brazilian regions. Another limitation was that the food intake amounts were self-reported. One of the possible consequences is prevalence overestimation, even though the amounts consumed were collected by interview. However, this limitation is also present in similar studies $5,8,10,12$. Moreover, studies that assessed the clustering of NCD risk factors found that the factors varied greatly, hindering direct comparison of the findings.

\section{CONCLUSION}

Given that the study behaviors are complex but modifiable, it is essential to identify population subgroups at greater risk of clustered risk factors to prevent NCD. The present findings may have a significant impact on health practices and policies because the high prevalence of NCD risk factor clustering found herein reinforces the need of NCD-preventive interventions. Although the results suggest that some student subgroups are more vulnerable, interventions should be implemented regardless of academic major duration, shift, time spent at the institution, gender, and socioeconomic status. Different strategies can be used, such as providing areas that consider student particularities for practicing physical activity and for learning about health and risk behaviors.

\section{ONTRIBUTORS}

RM TASSITANO conceived the study, analyzed and interpreted the results, wrote and made an 
important critical review of the article's intellectual content, and approved the final version for publication. MCM TENÓRIO interpreted the data, wrote and critically reviewed the article, and approved the final version for publication. PC CABRAL interpreted the data, wrote and critically reviewed the article, and approved the final version for publication. GAP SILVA conceived the study, analyzed and interpreted the results, wrote and made an important critical review of the article's intellectual content, and approved the final version for publication.

\section{REFERENCES}

1. World Health Organization. Global health risks: Mortality and burden of disease attributable to selected major risks. Geneva: WHO; 2009 [cited 2012 Jan 10]. Available from: <http://www.who.int/ healthinfo/global_burden_disease/globalhealth risks_report_full.pdf>.

2. World Health Organization. Preventing chronic diseases a vital investment. Geneva: WHO; 2005 [cited 2012 Jan 10]. Avaliable from: <http://www. who.int/chp/chronic_disease_report/full_report. $\mathrm{pdf}>$.

3. Mikkila V, Rasanen L, Raitakari OT, Pietinen P, Viikari J. Longitudinal changes in diet from childhood into adulthood with respect to risk of cardiovascular diseases: The cardiovascular risk in young finns study. Eur J Clin Nutr. 2004; 58(7):1038-45. doi: 10.1038/sj.ejcn.1601929

4. Ness AR, Maynard M, Frankel S, Smith GD, Frobisher C, Leary SD, et al. Diet in childhood and adult cardiovascular and all cause mortality: The Boyd Orr cohort. Heart. 2005; 91(7):894-8. doi: 10.1136/hrt.2004.043489

5. Alamian A, Paradis G. Correlates of multiple chronic disease behavioral risk factors in Canadian children and adolescents. Am J Epidemiol. 2009; 170(10): 1279-89. doi: 10.1093/aje/kwp284

6. Chiolero A, Wietlisbach V, Ruffieux C, Paccaud F, Cornuz J. Clustering of risk behaviors with cigarette consumption: A population-based survey. Prev Med. 2006; 42(5):348-53. doi: 10.1016/j.ypmed. 2006.01.011

7. Fine LJ, Philogene GS, Gramling R, Coups EJ, Sinha $S$. Prevalence of multiple chronic disease risk factors. 2001. National Health Interview Survey. Am J Prev Med. 2004; 27(2 Suppl):18-24. doi: 10.1016/ j.amepre.2004.04.017

8. Galan I, Rodriguez-Artalejo F, Tobias A, Diez-Ganan L, Gandarillas A, Zorrilla B. Clustering of behavior- related risk factors and its association with subjective health. Gac Sanit. 2005; 19(5):370-8.

9. Lawlor DA, O'Callaghan MJ, Mamun AA, Williams GM, Bor W, Najman JM. Socioeconomic position, cognitive function, and clustering of cardiovascular risk factors in adolescence: Findings from the Mater University Study of Pregnancy and its outcomes. Psychosom Med. 2005; 67(6):862-8. doi: 10.1097/ 01.psy.0000188576.54698.36

10. Poortinga $\mathrm{W}$. The prevalence and clustering of four major lifestyle risk factors in an English adult population. Prev Med. 2007; 44(2):124-8. doi: 10.10 16/j.ypmed.2006.10.006

11. Prochaska JO. Multiple health behavior research represents the future of preventive medicine. Prev Med. 2008; 46(3):281-5. doi: 10.1016/j.ypmed. 2008.01.015

12. Schuit AJ, van Loon AJ, Tijhuis M, Ocke M. Clustering of lifestyle risk factors in a general adult population. Prev Med. 2002; 35(3):219-24. doi: 10.1006/pmed. 2002.1064

13. Fine LJ, Philogene GS, Gramling R, Coups EJ, Sinha $S$. Prevalence of multiple chronic disease risk factors. 2001 National health interview survey. Am J Prev Med. 2004; 27 (2 suppl):18-24.

14. Dodd LJ, Al-Nakeeb Y, Nevill A, Forshaw MJ. Lifestyle risk factors of students: A cluster analytical approach. Prev Med. 2010; 51(1):73-7. doi: 10.10 16/j.ypmed.2010.04.005

15. Ammerman AS, Lindquist CH, Lohr KN, Hersey J. The efficacy of behavioral interventions to modify dietary fat and fruit and vegetable intake: A review of the evidence. Prev Med. 2002; 35(1):25-41. doi: 10.1006/pmed.2002.1028

16. Atkins D, Clancy C. Multiple risk factors interventions. Are we up to the challenge? Am J Prev Med. 2004; 27(2 Suppl):102-3. doi: 10.1016/j.amepre.2004. 04.016

17. Nigg CR, Allegrante JP, Ory M. Theory-comparison and multiple-behavior research: Common themes advancing health behavior research. Health Educ Res. 2002; 17(5):670-9. doi: 10.1093/her/17.5.6 70

18. Glanz K, Bishop DB. The role of behavioral science theory in development and implementation of public health interventions. Annu Rev Public Health. 2010; 31:399-418. doi: 10.1146/annurev. publhealth.012809.103604

19. Haase A, Steptoe A, Sallis JF, Wardle J. Leisure-time physical activity in university students from 23 countries: Associations with health beliefs, risk awareness, and national economic development. Prev Med. 2004; 39(1):182-90. doi: 10.1016/j.ypmed. 2004.01.028 
20. Harker D, Shama B, Harker M, Reinhard K. Leaving home: Food choice behavior of young German adults. J Bus Res. 2010; 63(2):111-5.

21. Lori AJ, Scott-Sheldon E, Carey KB, Carey MP. Health behavior and college students: Does Greek affiliation matter? J Behav Med. 2008; 31(1):61-70. doi: 10.1007/s10865-007-9136-1

22. Lowry R, Galuaka DA, Fulton JE, Wechsler H, Kann L, Collins JL. Physical activity, food choice, and weight management goals and practices among U.S. College Students. Am J Prev Med. 2000; 18(1): 18-27.

23. Barreto SM, Passos VM, Firmo JO, Guerra HL, Vidigal PG, Lima-Costa MF. Hypertension and clustering of cardiovascular risk factors in a community in Southeast Brazil: The Bambui health and ageing study. Arq Bras Cardiol. 2001; 77(6): 576-81. doi: 10.1590/s0066-782x2001001200 008

24. Lessa I, Araujo MJ, Magalhaes L, Almeida Filho N, Aquino $\mathrm{E}$, Costa MC. Clustering of modifiable cardiovascular risk factors in adults living in Salvador (BA), Brazil. Rev Panam Salud Publica. 2004; 16(2):131-7.

25. Pereira JC, Barreto SM, Passos VM. Cardiovascular risk profile and health self-evaluation in Brazil: A population-based study. Rev Panam Salud Publica. 2009; 25(6):491-8.

26. Tassitano RM, Feitosa WMN, Tenório MCM, Santiago Júnior GL. Simultaneidade de comportamentos de risco a saúde e fatores associados em trabalhadores da indústria. Rev Bras Ativ Fis Saúde. 2010; 15(1):42-9.

27. Colares V, França CD, Gonzalez E. Condutas de saúde entre universitários: diferenças entre gêneros.
Cad Saúde Pública. 2009; 25(3):521-28. doi: 10.15 90/S0102-311X2009000300007

28. Slater B, Philippi ST, Fisberg RM, Latorre MRDO. Validation of a semi-quantitative adolescent food frequency questionnaire applied at a public school in Sao Paulo, Brazil. Eur J Clin Nutr. 2003; 57(5): 629-35. doi: 10.1038/sj.ejcn.1601588

29. Craig $C L$, Marshall $A L$, Sjostrom M, Bauman $A E$, Booth ML, Ainsworth BE, et al. International physical activity questionnaire: 12-country reliability and validity. Med Sci Sports Exer. 2003; 35(8):1381-95.

30. Associação Brasileira de Empresas de Pesquisa. Critério de Classificação Econômica Brasil. Brasília: Abep; 2010 [acesso 2010 out 18]. Disponível em: $<$ http://www.abep.org >

31. Marcondelli P, Costa THM, Schmitz BAS. Nível de atividade física e hábitos alimentares de universitários do $3^{\circ}$ ao $5^{\circ}$ semestres da área de saúde. Rev Nutr. 2008; 21(1):39-47. doi: 10.1590/S141552732008000100005

32. Jaime PC, Monteiro CA. Consumo de frutas e hortaliças na população adulta brasileira, 2003. Cad Saúde Pública. 2005; 21(Supl 1):S19-S24.

33. Brasil. Ministério da Saúde. Dia mundial da saúde: perfil da alimentação e atividade física da população brasileira. Brasília: Ministério da Saúde; 2009 [acesso 2011 abr 10]. Disponível em: <http://portal. saude.gov.br/portal/arquivos/pdf/vigitel _2009_ preliminar_web_20_8_10.pdf>.

Received on: 5/12/2012

Final version on: 21/10/2013

Approved on: 26/11/2013 